\title{
Biomass from field crop production as an energy source and a new activity area for economic operators at a local level*
}

\author{
Zbigniew Brodziński1, Krystyna Kurowska², Hubert Kryszk² \\ 1 Faculty of Economics, University of Warmia and Mazury in Olsztyn, Poland \\ 2 Faculty of Geodesy, Geospatial and Civil Engineering, Department of Planning and Spatial Engineering, University of Warmia \\ and Mazury in Olsztyn, Poland
}

Corresponding author: Zbigniew Brodziński, Department of Spatial and Environmental Economics, Faculty of Economics, University of Warmia and Mazury in Olsztyn, Oczapowskiego 4, 10-719 Olsztyn, Poland; Phone: +48 08952338 22; E-mail: zbr@uwm.edu.pl

Key words: biomass, energy policy, RES, rural areas, sustainable development

Received in September 2013. Published in April 2015.

\begin{abstract}
The need for development of renewable energy sources (RES) results from both the current situation in the energy sector in Poland and the measures taken by the European Union, i.e. meeting EU commitments regarding increasing the share of energy generated from renewable sources by 2020 . Energy
\end{abstract}

derived from RES is favourable for both reduction of pollutant emissions to the atmosphere and water, and reduction of the volume of waste generated. This paper identifies the potential of biomass production for energy purposes in the region of Warmia and Mazury (Poland), which could be a key action for sustainable development of rural areas and investment activity.

\section{INTRODUCTION}

Energy from renewable energy sources (RES) comes from non-fossil sources (wind, solar, aerothermal, geothermal, hydrothermal and ocean energy, hydropower, biomass, landfill gas, sewage treatment plant gas and biogases) (Directive 2009). Renewable energy has become increasingly important in Poland because traditional energy sources are being depleted (Kryszk and Kurowska 2014). Over the long term, developing the energy sector to make use of renewable resources will allow use of the potential production capacity of cropland and compliance with environmental requirements (Wereszczaka 2010). As noted by Faber (2008), the renewable energy sector in Poland is in its formative stage. The main obstacle to its development is the absence of a firm policy for renewable energy development.

Poland has the opportunity to develop its renewable energy sector not only by building large power plants, but also by investing in scattered micro-sources of energy derived from biomass. These micro-sources are located in rural areas, which make up $93 \%$ of the total area of the country. $65 \%$ of these rural areas are arable land and grassland, including class $\mathrm{V}$ and VI land (of low agricultural value). Indeed, the potential for utilizing these areas is great (Wereszczaka 2010), because approximately 15 million ha of agricultural land are available, of which it is estimated that only 4-5 million are necessary to meet food requirements (Lampart and Kowalski 2010).

\section{Biomass as a primary source of renewable energy}

Biomass is a huge reservoir of energy that is widely available from agriculture, forestry, the fishing industry and aquaculture, and it also includes the biodegradable fraction of industrial and municipal waste (Directive 2009). The energy stored in biomass is the least capital intensive source of renewable energy (Niedziółka 2012). It can be burned in household stoves, or converted into biofuels, or electricity and heat energy, in technologically advanced biomass power plants, biogas plants and biorefineries. Biomass should be able to cover a significant

\footnotetext{
* Presented at the Fourth International Environmental Best Practices Conference, 8-12 September 2013, Olsztyn, Poland
} 
proportion of the demand for energy, assuming that highperformance biomass production and processing technologies are employed (Lampart and Kowalski 2010). In Poland, biomass of agricultural origin makes up about $85 \%$ of RES (Stolarski 2012). This biomass is usually a byproduct of food production, which means that agriculture and energy production are closely related (Robles and Dalia 2011).

As noted by Jasiulewicz (2012), potential profitability of biomass production for energy purposes is mostly dependent on both the prices of raw materials used for energy purposes and the guaranteed multiannual market for the biomass. The produced biomass should preferably originate from local sources, i.e. from agriculture, municipal waste or from industry. Where traditional crop cultivation for energy purposes or energy crop plantations are the basic options for producing agricultural biomass, an appropriate large-scale model of biomass production should be tested.

It is estimated that by 2020 biomass could provide approximately $2 / 3$ of the declared share of energy generated from RES in the EU countries. The advantages of biomass include: constant availability (unlike solar energy or wind power), price competitiveness (cheaper than fossil fuels) and its suitability for generating electricity, heating and transport related purposes. Developing system for biomass production may benefit rural development (Zielińska 2008).

The main measures being taken in Poland for the development of biomass energy include:

- Subsidies to investors and bioenergy producers.

- Promotion of renewable fuels in transport between 2008-2014.

- Construction of agricultural biogas plants with the assumption that at least one biogas plant will be established in each commune by 2020 .

- Development of technical facilities for biomass energy generation and processing (Lampart and Kowalski 2010).

\section{Factors influencing biomass production and processing in Warmia and Mazury}

The development of renewable energy sources depends primarily on setting up an integrated system for biomass production and processing as well as on the energy distribution. The effective use of biomass in energy generation would require the establishment of local energy centres across rural areas, which would stimulate rural development by creating new jobs, comprehensive use of land and circulating capital at the local level (Gostomczyk 2009; Jasiulewicz 2012; RenigerBiłozor and Gobczyński 2011).

Rural areas in Warmia and Mazury show spatial variation in terms of their function. Agriculture is major industry utilizing $54.56 \%$ of the total area of the region. According to the Agency for Restructuring and Modernisation of Agriculture (ARMA) (CSO 2012), in 2012 the average area of agricultural holding was $22.88 \mathrm{ha}$, while the national average was only 10.38 ha. There has been a continuous decrease in the number of agricultural holdings, particularly in the case of small holdings being absorbed by the larger ones (over 15ha). These factors as well as significant human resources make the region favourable for such development.

In Warmia and Mazury the arable land accounts for $67.14 \%$ of the total area of agricultural land. Grassland includes permanent pastures $(17.32 \%)$ and permanent meadows (12.48\%). Podsolic and brown soils and luvisols predominate. The most favourable conditions for agriculture are found in the northern (predominance of brown soils) and north-western parts of the region, while the least favourable ones are in its southern part, where podsolic soils predominate.

The mixture of difficult agricultural conditions and the concentration of production in larger holdings are conducive to the development of biomass production for energy purposes.

The aim of this paper is to present the factors determining the production of biomass for energy purposes in Warmia and Mazury. Particular attention was paid to the factors affecting the development of the biomass market. Furthermore, on the basis of the opinions of regional biomass producers and processors, an attempt was made to predict changes in the demand for renewable energy within the next few years.

\section{MATERIALS AND METHODS}

Studies were based on a field survey conducted in 2012. The survey used questionnaires distributed to all 123 farmers who declared production of biomass for energy purposes (producers), as well as 30 entrepreneurs involved in biomass processing (processors) under the program Social and Economic Conditions for the Development of Ethanol Fuel Production from Biomass. The list of the research participants was based on information obtained from advisors of the Warmia and Mazury Agricultural Advisory Centre (W-MODR) in Olsztyn, which is involved in addressing the issues of RES development. Information provided by 108 producers and 27 processors was used for further analyses as 15 producers and 3 processors were no longer involved in such activities. The full survey questionnaires are available on the website of the Centre for Renewable Energy Research:

- Concerning biomass producers: http://www.uwm.edu.pl/cbeo/wpcontent/uploads/2015/Kwestionariusz_OZE_ producenci.pdf.

- Concerning biomass processors http://www.uwm.edu.pl/cbeo/wp-content/uploads/2015/ Kwestionariusz_OZE_przetworcy.pdf.

As part of our research, farmers involved in biomass production for energy purposes were asked to indicate and rate, on a 5-point scale (where 1 is the lowest score) the factors which they felt affect the present situation of the biomass production sector. 


\section{RESULTS AND DISCUSSION}

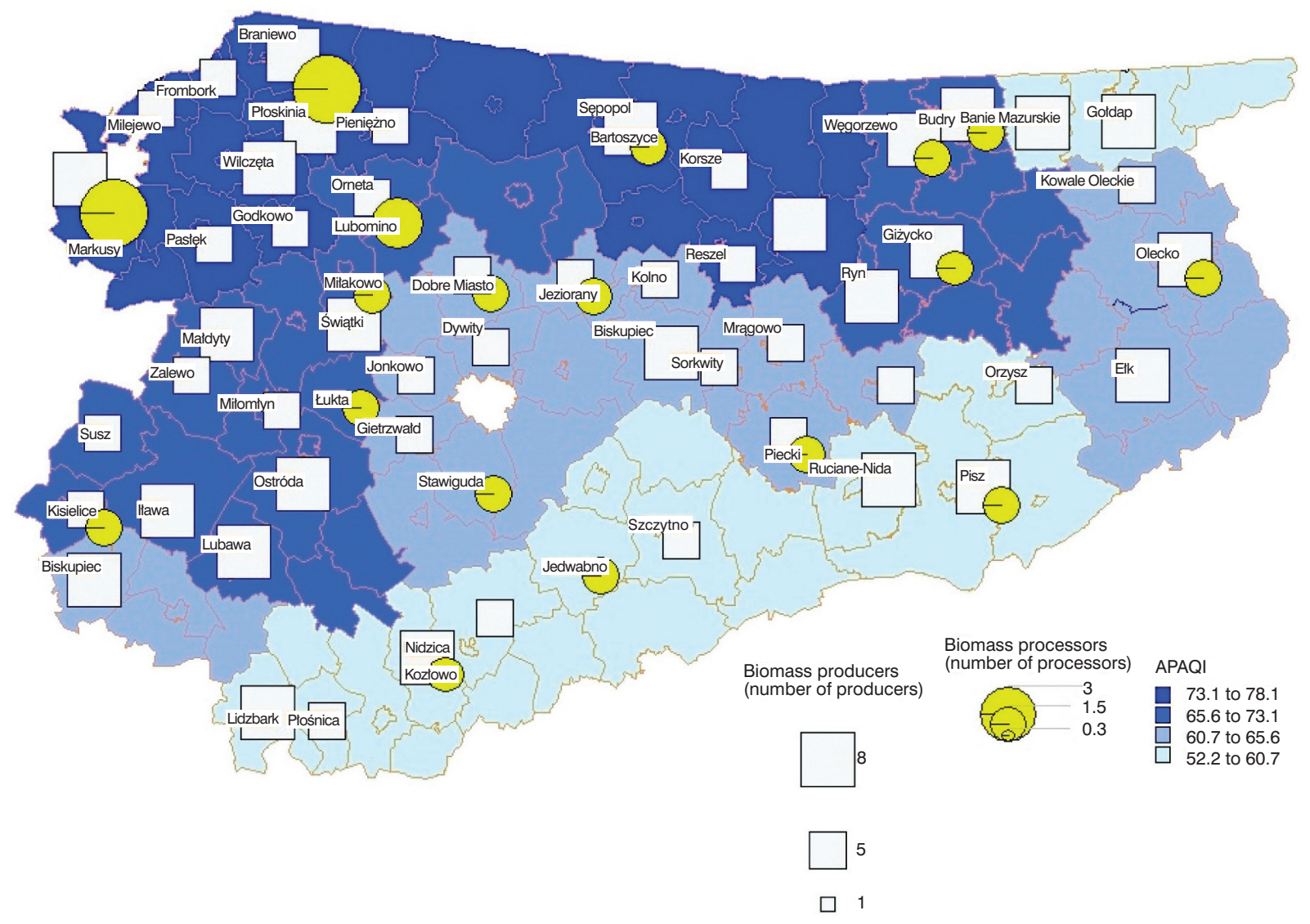

Figure 1. Distribution of biomass producers and processors in Warmia and Mazury (Poland) against the background of agricultural production area quality index (APAQI). Based on survey research and the Institute of Soil Science and Plant Cultivation (IUNG) data (Witek 1981).

In Warmia and Mazury the biomass producers are mainly located in the western and north-eastern part of the region (Figure 1). Location of a plantation in relation to the potential reception points is an important element as transport costs are the most important factor affecting profitability. These include distance, material and processes involved (Zarębski 2010). Location of the producers and adjustment of the quality of raw materials to the demands of their processors determine satisfactory revenue of the producers.

Entrepreneurs who purchase and process the biomass consider the north-western part of Warmia and Mazury as best suited for profitable production of the biomass. In the central part of the region only single processors are found, while in the central-northern and north-eastern part there are few producers and processors (Figure 1). Most activity is located in those parts of the region where the agricultural production area quality index (APAQI) is at an average level.
We have identified the main restrictions affecting the development of renewable energy production:

- Aversion of the public to the location of such projects in the neighbourhood.

- Low public awareness of the role and significance of RES.

- Lack of stable governmental support for this new area of economic activity.

- Lack of adaptation of the proposed technologies to the local conditions.

- High costs of installations.

- Problems associated with the connection of new installations to the power and heat supply networks.

- Lack of stable legal solutions that would encourage the activities of various groups of RES operators in the energy market.

- Underdeveloped power network in rural areas (Pyka 2007; Reniger-Biłozor and Gobczyński 2011). 


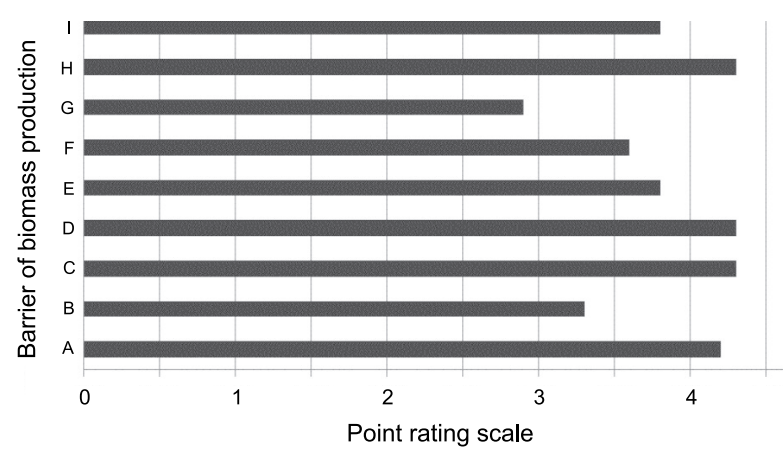

Figure 2. Determinants of biomass production for energy purposes in opinions of its producers from Warmia and Mazury (Poland). Average values in points of a rating scale: (A) the absence of a developed market of biomass receivers, (B) the absence of appropriate knowledge among farmers on the establishment and maintenance of crop plantations for energy purposes, (C) unsatisfactory level of prices being achieved for biomass, (D) the absence of programmes for support of RES development, (E) unsatisfactory status of development and modernisation of plants processing or using biomass for energy purposes, (F) high costs of biomass production, (G) restricted access to sources of knowledge on the opportunities for production and use of biomass for energy purposes, $(\mathrm{H})$ the absence of aid for crop plantations for energy purposes, (I) the absence of specialised equipment for cultivation and harvesting of biomass for energy purposes. Source: Point 10 of the questionnaire http://www.uwm.edu.pl/cbeo/wp-content/uploads/ 2015/Kwestionariusz_OZE_producenci.pdf, accessed February 2, 2015.

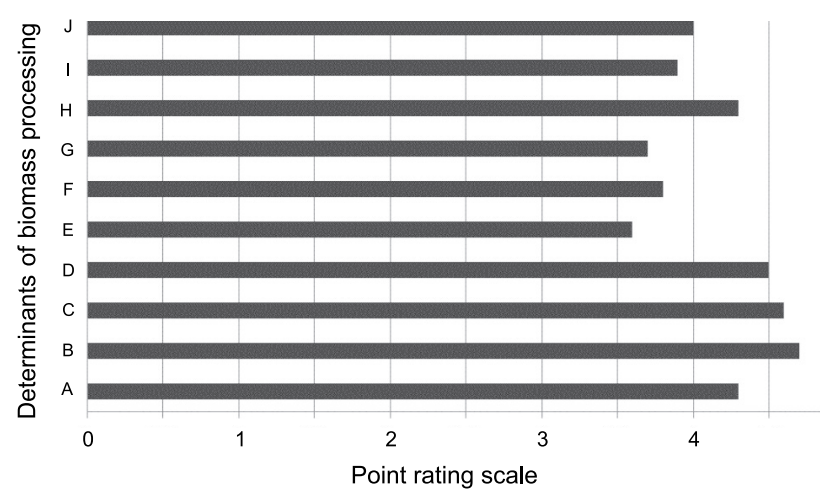

Figure 3. Determinants of biomass processing for energy purposes in opinions of biomass processors of Warmia and Mazury (Poland). Average values in points of a rating scale: (A) high costs of the establishment of crop plantation, (B) the absence of market, (C) too low prices of biomass, (D) no stable prices for raw materials, (E) large supply of biomass from forests etc., (F) the absence of an organised harvesting system, (G) difficulties associated with the harvesting technique, $(\mathrm{H})$ long distance between the place of origin and the place of biomass processing, (I) low competitiveness as compared to other crops not intended for energy purposes, $(\mathrm{J})$ producers not being convinced that it is a profitable direction of agricultural production.

Source: Point 11.b of the questionnaire http://www.uwm.edu.pl /cbeo/wp-content/uploads/2015/Kwestionariusz_OZE_ przetworcy.pdf, accessed February 2, 2015.
Other, equally important, restrictions affecting development of renewable energy production are:

- Low level of prices for biomass.

- Lack of specialised equipment for cultivation and harvesting of the biomass.

- Lack of satisfactory equipment for biomass processing (Figure 2).

Furthermore, producers felt they lacked knowledge on biomass production and satisfactory access to such information. Barriers restricting the development of biomass production might be minimised by more effective financial support to the biomass producers and by improved State policy on RES.

For the entrepreneurs involved in biomass transportation and processing the most important problems included poorly developed market and unsatisfactory prices of processed biomass, as well as frequent price fluctuations and the need for transportation of raw materials over long distances (Figure 3).

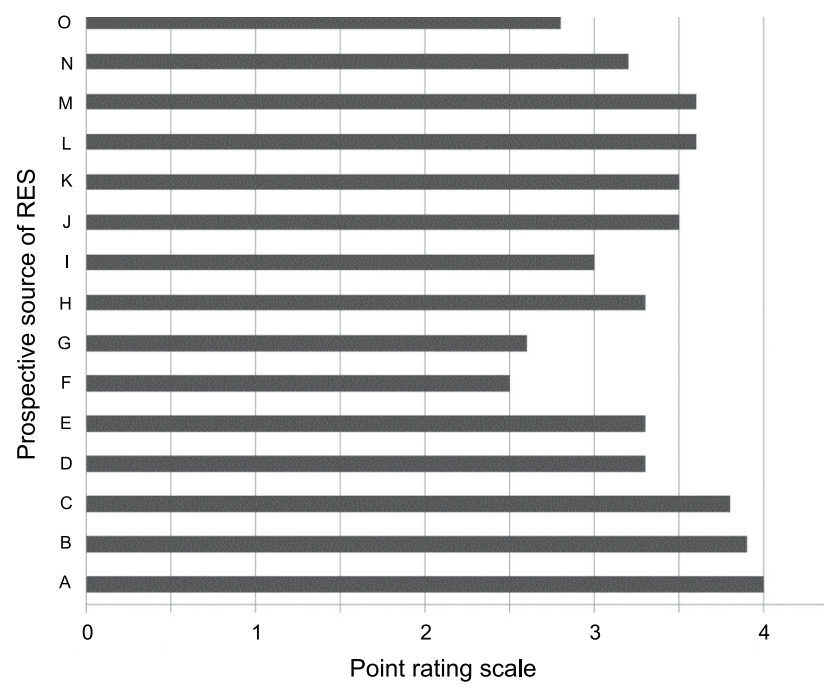

Figure 4. The main prospective sources of supplies of energy from renewable energy sources [RES] in the opinions of biomass producers of Warmia and Mazury (Poland). Average values in points of a rating scale: (A) energy from solar sources, (B) wind power, (C) energy from biomass, (D) geothermal energy, (E) water energy, (F) energy from coal, (G) energy from crude oil, (H) energy from gas, (I) energy from other conventional sources, (J) energy crops (maize, grains, ...), (K) perennial energy crops, (L) waste (agricultural, municipal, ...), (M) straw, (N) wood (wood waste, industrial waste, ...), (O) import of biomass of varied origin.

Source: Point 21 of the questionnaire http://www.uwm.edu.pl/ cbeo/wp-content/uploads/2015/Kwestionariusz_OZE_ producenci.pdf, accessed February 2, 2015.

It is important to identify prospective demand for RES. According to Zielińska (2008), the significance of RES is increasing. Producers envisage greater development of solar energy, followed by the energy produced from biomass and from the wind power (Figure 4). What is particularly curious 
it is the expectation for the development of the wind power, given the strong resistance of local communities to the location of wind farms in their area.

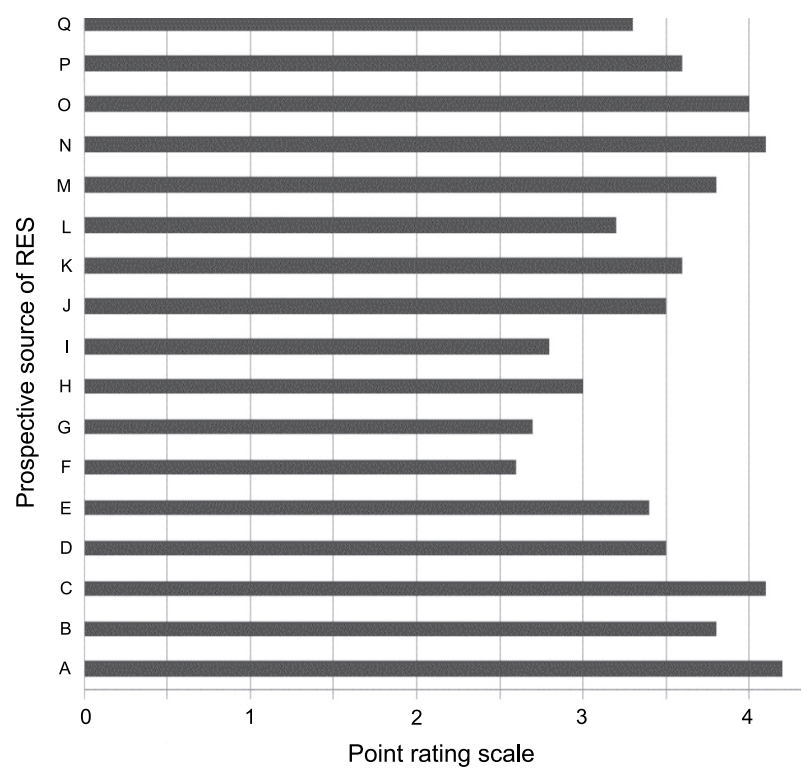

Figure 5. Prospects of demand for energy from renewable energy sources [RES] in the opinions of biomass processors of Warmia and Mazury (Poland). Average values in points of a rating scale: (A) import of biomass of varied origin, (B) wood (wood waste, industrial waste, ...), (C) straw, (D) waste (agricultural, municipal, ...), (E) perennial energy crops, (F) root plants (sugar beet, potato, ...), (G) oil-bearing plants (rape, turnip rape), (H) energy crops (maize, grains, ...), (I) energy from other conventional sources, $(\mathrm{J})$ energy from gas, $(\mathbf{K})$ energy from crude oil, (L) energy from coal, (M) water energy, (N) geothermal energy, (O) energy from biomass, (P) energy from wind, $(Q)$ energy from solar sources.

Source: Point 21 of the questionnaire http://www.uwm.edu.pl /cbeo/wp-content/uploads/2015/Kwestionariusz_OZE_ przetworcy.pdf, accessed February 2, 2015.

For the processors the first 3 options of RES were rated similarly, whereas the entrepreneurs involved in purchasing, transporting and processing rated the development of wind energy lower than the producers. These entrepreneurs focused primarily on the use of straw, waste and biomass derived from perennial energy crops (Figure 5).

\section{SUMMARY AND CONCLUSIONS}

In Poland there is a potential for the development of renewable energy using biomass of agricultural origin. This is consistent with the direction of the development of renewable energy in the European Union. The economic viability of renewable energy depends directly on subsidies provided for the production of renewable energy sources and on stable and favourable regulations for the sector.
Biomass energy provides social and economic potential for the region which is economically neglected and has significant resources of agricultural land. Bearing in mind that the regional development is affected by external determinants (including predictability of socio-economic changes and policy in relation to rural areas), the greater attention needs to be focused on the local determinants. Prior to the integration of Poland with the EU there was an uncertain approach to rural development and reform, especially in economic and social areas. However, when Poland became an EU member, rural development policy became more predictable, which encourages development programmes as the potential risks are significantly reduced. For the above reasons, the national policy (correlated with the EU energy policy) may be seen to assist in supporting and correcting development processes. The particular role of integrated systems for acquiring and processing biomass for energy purposes primarily results from the need for efficient use of the resources existing in rural areas (mainly land and labour force).

In conclusion, local strategies and programmes must address the following issues:

- The possibilities for long-term cooperation with the existing municipal heating plants as potential biomass receivers.

- The need for setting up systems for the production, harvesting and use of biomass within larger areas of administration (several communes or districts).

- Involvement of the local communities in developing the production and use of energy derived from RES, underlining the fact that biomass energy is not only a new trend in meeting energy needs but also promotes professional activation of the local populations and greater rural development.

\section{ACKNOWLEDGEMENTS}

The strategic program of the National (Polish) Centre for Research and Development (NCBiR): "Advanced Technologies for Energy Generation. Task 4: Elaboration of Integrated Technologies for the Production of Fuels and Energy from Biomass, Agricultural Waste and other Waste Materials.“

\section{REFERENCES}

CSO. 2012. Statistical Yearbook Warmińsko-Mazurskie Voivodship. 2012. Statistical Office in Olsztyn, 58 p.

Directive 2009/28/EC of the European Parliament and of the Council of 23 April 2009 on the promotion of the use of energy from renewable sources and amending and subsequently repealing Directives 2001/77/EC and 2003/30/EC.

Faber, A. 2008. Polskie doświadczenia i osiągnięcia w dziedzinie bioenergii [Polish experiences and achievements in the field of bioenergy]. Departament Polityki Ekonomicznej, Ministerstwo Spraw 
Zagranicznych, Warszawa [Department of Economic Cooperation, Ministry of Foreign Affairs, Warsaw], pp. 19-55 (in Polish) http://ksow.pl/fileadmin/user_upload/ksow.pl/pliki/ANALIZY_ekspert yzy/Energia_odnawialna_i_jej_znaczenie_dla_rozwoju_obszar\% $\%$ C3\% B3w_wiejskich.pdf, accessed June 15, $201 \overline{3}$.

Gostomczyk, W. 2009. Wykorzystanie biomasy do celów energetycznych w kreowaniu rozwoju obszarów wiejskich i miejsc pracy [The use of biomass for energy purposes in the creation of rural development and employment]. In: Energetyczne wykorzystanie biomasy w działalności gospodarczej [Energy use of biomass in business] (ed. M. Jasiulewicz), pp. 179-198. Politechnika Koszalińska, Koszalin (in Polish).

Jasiulewicz, M. 2012. Opportunities for rural area development stimulation through agrotourism and the production of raw energy material in the Koszalin Subregion. Acta Scientiarum Polonorum. Administratio Locorum 11: 89-96 (in Polish).

Kryszk, H., K. Kurowska. 2014. Fotowoltaika jako źródło energii odnawialnej i nowy obszar aktywności na obszarach wiejskich [Photovoltaics as a source of renewable energy and a new area of activity in rural areas]. In: Studia obszarów wiejskich. Regionalny wymiar przemian polskiej wsi - aspekty społeczne i środowiskowe [Rural Studies. Regional Dimension of Changes in Polish Rural Areas - Social and Environmental Aspects] (ed. M. Wójcik), Volume 35, pp. 253-272. PAN, IGiPZ, Warsaw (in Polish).

Lampart, P., P. Kowalski. 2010. Kogeneracja w oparciu o źródła biomasy/biogazu [Biomass/Biogas Cogeneration]. In: Ekoenergetyka - zagadnienia technologii, ochrony środowiska i ekonomiki [Ekoenergetyka - Issues of Technology, Environment and Economy] (ed. A. Cenian, T. Noch), pp. 121-144. Wydawnictwo Gdańskiej Wyższej Szkoły Administracji, Gdańsk (in Polish).

Niedziółka, D. (ed.). 2012. Zielona energia w Polsce [Green Energy in Poland]. 179 p. CeDeWu - Wydawnictwa Fachowe, Warszawa (in Polish).

Pyka, J. (ed.) 2007. Szanse i zagrożenia rozwoju rynku energetycznego w Europie i w Polsce [Opportunities and Threats of Development the Energy Market in Europe and Poland], pp. 66-68. Wydawnictwo AE w Katowicach, Katowice (in Polish).

Reniger-Biłozor, M., K. Gobczyński. 2011. Efektywność zastosowania odnawialnych źródeł energii w gospodarce nieruchomościami mieszkaniowymi - część II [Efficiency of Renewable Energy Generation Utilization in the Residential Buildings Management - Part II]. Acta Scientarum Polonorum. Admnistratio Locorum 10: 73-85 (in Polish).
Robles R., P. Dalia. 2011. Interactions between agriculture and energy policies: the case of Castile and Leon (Spain). In: Rural Development 2011. The fifth international scientific conference. Aleksandras Stulginskis University, Kaunas, Volume 5, Book 1: 222-228.

Stolarski, M. 2012. Perspektywy wykorzystania odnawialnych źródeł energii [Prospects for the use of renewable energy sources]. In: Stan obecny i perspektywy rozwoju obszarów wiejskich w województwie warmińsko-mazurskim do 2020 roku [Current Status and Prospects of Development of Rural Areas in the Warmia-Mazury 2020] (ed. Z. Brodziński), pp. 79-98. Samorząd Województwa Warmińsko-Mazurskiego, Olsztyn (in Polish).

Wereszczaka, J. 2010. Produkcja biomasy jako energetycznego surowca odnawialnego i utylizacja pofermentu [Biomass production as energy resources and utilization of digestion residue]. In: Ekoenergetyka - zagadnienia technologii, ochrony środowiska i ekonomiki [Ekoenergetyka - Issues of Technology, Environment and Economy] (ed. A. Cenian, T. Noch), pp. 224239. Wydawnictwo Gdańskiej Wyższej Szkoły Administracji, Gdańsk (in Polish).

Witek, T. 1981. Waloryzacja rolniczej przestrzeni produkcyjnej Polski według gmin [Valorisation of agricultural production areas of Poland by gminas], pp. 334-410. Instytut Uprawy Nawożenia i Gleboznawstwa w Puławach [Institute of Soil Science and Plant Cultivation in Puławy] (in Polish).

Zarębski, P. 2010. Investment attractiveness of the communes of Pomeranian province for economic undertakings related to the production of energy from renewable sources. In: Ekoenergetyka - zagadnienia technologii, ochrony środowiska i ekonomiki [Ekoenergetyka - Issues of Technology, Environment and Economy] (ed. A. Cenian, T. Noch), pp. 257-268. Wydawnictwo Gdańskiej Wyższej Szkoły Administracji, Gdańsk (in Polish).

Zielińska, M. 2008. Rola energii odnawialnej w zrównoważonym rozwoju obszarów wiejskich - przegląd unijnych strategii [The role of renewable energy in sustainable rural development a review of the EU strategy]. Departament Polityki Ekonomicznej, Ministerstwo Spraw Zagranicznych, Warszawa [Department of Economic Cooperation, Ministry of Foreign Affairs, Warsaw]. 71 p. (in Polish). http://ksow.pl/fileadmin /user_upload/ksow.pl/pliki/ANALIZY_ekspertyzy/Energia_od nawialna_i_jej_znaczenie_dla_rozwoju_obszar\%C3\%B3w_wiej skich.pdf, accessed June $\overline{15}, 2013$. 